\title{
Clinical and community genetics services in the Dutch Caribbean
}

\author{
Eline A. Verberne ${ }^{1}$ (D) - Ginette M. Ecury-Goossen ${ }^{2} \cdot$ Meindert E. Manshande $^{2} \cdot$ Maria Ponson-Wever $^{3} \cdot$ \\ Maartje de Vroomen ${ }^{4,5} \cdot$ Martijn Tilanus $^{6} \cdot$ Marcel M. A. M. Mannens $^{1} \cdot$ Lidewij Henneman $^{7}$ (D) Mieke M. van Haelst ${ }^{1,7}$
}

Received: 11 December 2020 / Accepted: 1 March 2021 / Published online: 10 March 2021

(C) The Author(s), under exclusive licence to Springer-Verlag GmbH Germany, part of Springer Nature 2021

\begin{abstract}
The Caribbean part of the Kingdom of the Netherlands consists of six islands: Aruba, Bonaire, Curaçao, St. Maarten, St. Eustatius, and Saba. Because of their small size and relative remoteness, they face several economic and healthcare challenges, including limited access to genetics services. In this article, we provide an overview of the clinical and community genetics services that are available in the Dutch Caribbean. In particular, we describe our joint pediatric-genetics clinic with a visiting clinical geneticist that was established in 2011 to provide clinical genetics services for the pediatric population of the Dutch Caribbean.
\end{abstract}

Keywords Dutch Caribbean $\cdot$ Genetics services $\cdot$ Clinical genetics $\cdot$ Community genetics

\section{Introduction}

\section{History and general characteristics of the Dutch Caribbean}

The Dutch Caribbean consists of six islands located in the Caribbean Sea that are part of the Kingdom of the Netherlands (Fig. 1). In 1954, after being part of the Dutch colony of Curaçao and Dependencies, these islands were

Mieke M. van Haelst

m.vanhaelst@amsterdamumc.nl

1 Department of Clinical Genetics and Amsterdam Reproduction \& Development Research Institute, Amsterdam UMC, University of Amsterdam, Amsterdam, The Netherlands

2 Department of Pediatrics, Curaçao Medical Center, Willemstad, Curaçao

3 Department of Pediatrics, Dr. Horacio E. Oduber Hospital, Oranjestad, Aruba

4 Department of Pediatrics, Fundashon Mariadal, Kralendijk, Bonaire, The Netherlands

5 Department of Pediatrics, Amsterdam UMC, Vrije Universiteit, Amsterdam, The Netherlands

6 Department of Pediatrics, St. Maarten Medical Center, Cay Hill, St. Maarten

7 Department of Clinical Genetics and Amsterdam Reproduction \& Development Research Institute, Amsterdam UMC, Vrije Universiteit, Amsterdam, The Netherlands united into a single country - the Netherlands Antilleswithin the Kingdom of the Netherlands. The island of Aruba seceded from the Netherlands Antilles in 1986 and became a separate constituent country of the Kingdom of the Netherlands. In 2010, the Netherlands Antilles were dissolved and Curaçao and St. Maarten became constituent countries within the Kingdom of the Netherlands as well, while Bonaire, St. Eustatius, and Saba (BES-islands) became special municipalities of the Netherlands. Together, these six islands are still commonly referred to as the Dutch Caribbean.

Curaçao is the largest of the six islands, with a population of 156,223 (Central Bureau of Statistics Curaçao 2020). The smallest island, Saba, has a population of only 1933 (Statistics Netherlands 2020). The population of the Dutch Caribbean is of mixed ancestry, with high migration rates during the last decades. The majority of the population is of Afro-Caribbean descent, with the exception of Aruba, that has a population of predominantly Amerindian origin (Toro-Labrador et al. 2003). Papiamentu is the most widely spoken language on the islands of Aruba, Bonaire, and Curaçao. On the islands located north of the long Lesser Antilles archipelago (St. Maarten, St. Eustatius, and Saba), English is most commonly used. The majority of the population is religious, with Roman Catholicism as the main religion. Further characteristics are summarized in Table 1. As the islands of the Dutch Caribbean are small and relatively remote, they are vulnerable to economic and environmental challenges. In 2017, hurricane Irma had a devastating effect on St. Maarten and its economy. Currently (in 2020/2021), the COVID-19 pandemic has a 


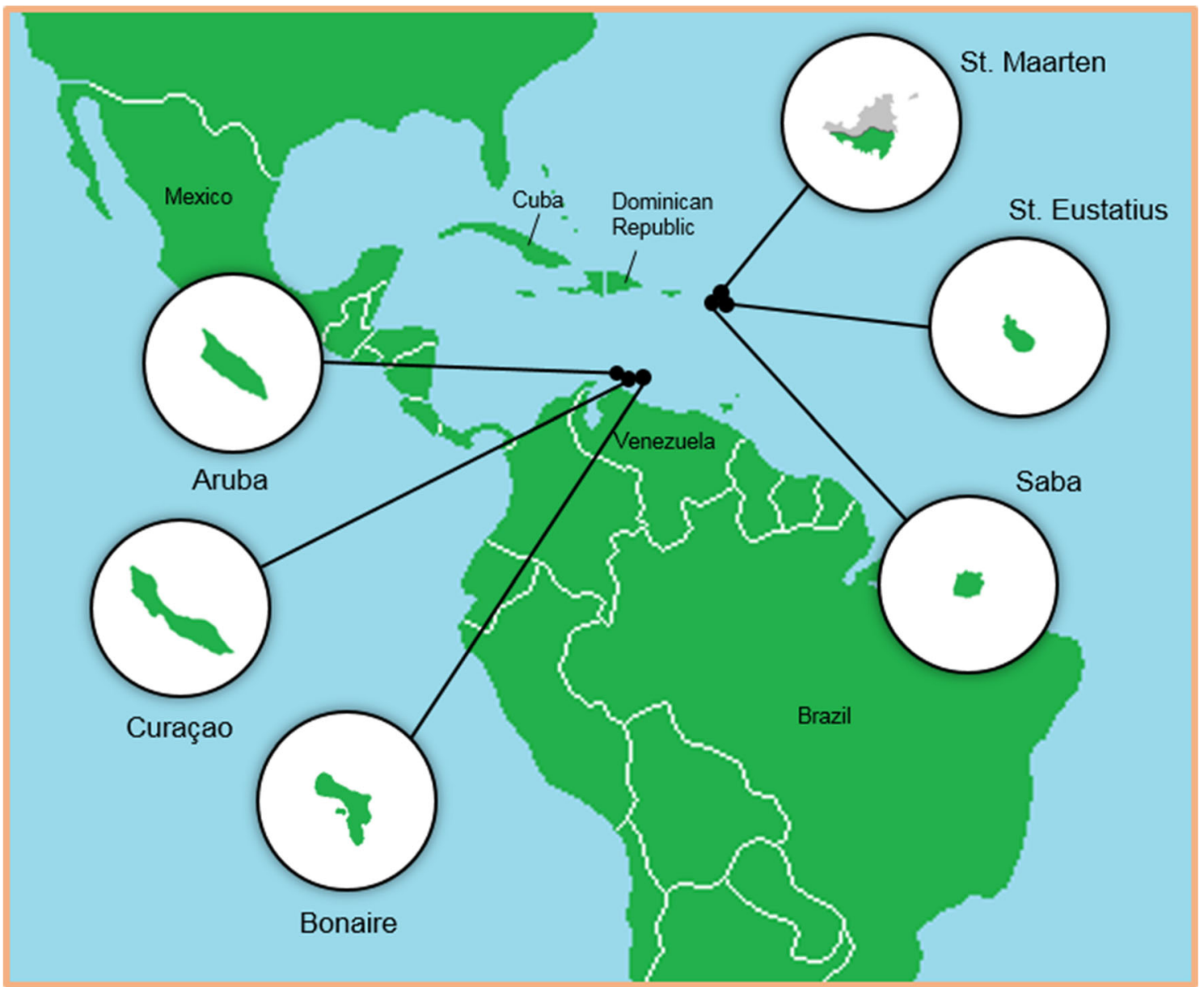

Fig. 1 Caribbean part of the Kingdom of the Netherlands. Aruba, Curaçao, and St. Maarten are constituent countries of the Kingdom of the Netherlands, while Bonaire, St. Eustatius, and Saba are special municipalities of the Netherlands

huge impact on the economies of the Dutch Caribbean, as they highly depend on tourism.

\section{Healthcare in the Dutch Caribbean}

The healthcare systems of the Dutch Caribbean largely mirror that of the Netherlands, with a general practitioner as the first point of contact. Secondary care is provided at hospitals and private clinics. All legal residents of Aruba, Curaçao, and the BES-islands are entitled to a basic health insurance, which is paid through income tax. In St. Maarten, there is no universal health coverage (yet). There are two general hospitals in Curaçao. The main hospital, Curaçao Medical Center, offers the most specialized medical care of the six islands, including pediatric cardiology and a neonatal intensive care unit. Aruba and St. Maarten each have one hospital that offers all major medical specialties. In Bonaire, secondary care is provided at the hospital Fundashon Mariadal. In St. Eustatius and Saba, there are no hospitals that provide secondary care, as both are very small islands, but each island has a medical center. Secondary care is provided by visiting medical specialists and through medical transfers to St. Maarten, St. Martin,
Colombia, and Guadeloupe. On all six islands, certain specialized care that is not locally available is provided through medical transfers to one of the neighboring islands, to Colombia or to the Netherlands. Visiting medical specialists from the Netherlands provide additional (specialized) care on a regular basis. For example, an otorhinolaryngologist visits Aruba twice a year to place cochlear implants and a pediatric neurologist visits Curaçao once a year to evaluate complex patients.

\section{Genetic diseases in the Dutch Caribbean}

With a large part of the population being of African descent, sickle cell disease, thalassemia, and glucose-6-phosphate dehydrogenase (G6PD) deficiency are relatively common monogenic disorders in the Dutch Caribbean (RIVM 2013; van der Dijs et al. 1992; van Heyningen et al. 2009). Another genetic disease that is prevalent in the Dutch Caribbean is hereditary hemorrhagic telangiectasia (HHT), or Rendu-Osler-Weber disease. This is a rare autosomal dominant disorder characterized by the presence of multiple arteriovenous malformations. The point prevalence of HHT in 
Table 1 General characteristics of the Dutch Caribbean

\begin{tabular}{|c|c|c|c|c|c|c|}
\hline & \multicolumn{3}{|l|}{ Constituent countries } & \multicolumn{3}{|c|}{ Special municipalities of the Netherlands } \\
\hline & Aruba & Curaçao & St. Maarten & Bonaire & St. Eustatius & Saba \\
\hline Capital $^{\mathrm{a}}$ & Oranjestad & Willemstad & Philipsburg & Kralendijk & Oranjestad & The Bottom \\
\hline Area $^{a}$ & $180 \mathrm{~km}^{2}$ & $444 \mathrm{~km}^{2}$ & $34 \mathrm{~km}^{2}$ & $288 \mathrm{~km}^{2}$ & $21 \mathrm{~km}^{2}$ & $13 \mathrm{~km}^{2}$ \\
\hline Population & $\begin{array}{l}112,190 \text { (January } 1, \\
2020)^{\mathrm{b}}\end{array}$ & $\begin{array}{l}156,223 \text { (January 1, } \\
2020)^{\mathrm{c}}\end{array}$ & $\begin{array}{l}\text { 40,614 (January } 1, \\
2018)^{\mathrm{d}}\end{array}$ & $\begin{array}{l}20,915 \text { (January } 1, \\
2020)^{\mathrm{e}}\end{array}$ & $\begin{array}{l}3,139 \text { (January } 1 \\
2020)^{\mathrm{e}}\end{array}$ & $\begin{array}{l}\text { 1,933 (January 1, } \\
2020)^{\mathrm{e}}\end{array}$ \\
\hline $\begin{array}{l}\text { Population } \\
\text { density }\end{array}$ & $623 / \mathrm{km}^{2}$ & $352 / \mathrm{km}^{2}$ & $1195 / \mathrm{km}^{2}$ & $73 / \mathrm{km}^{2}$ & $149 / \mathrm{km}^{2}$ & $149 / \mathrm{km}^{2}$ \\
\hline $\begin{array}{l}\text { Live } \\
\text { births/year }\end{array}$ & $1029(2019)^{\mathrm{b}}$ & $1583(2019)^{\mathrm{c}}$ & $363(2017)^{\mathrm{d}}$ & $203(2019)^{\mathrm{f}}$ & $30(2019)^{\mathrm{f}}$ & $11(2019)^{\mathrm{f}}$ \\
\hline $\begin{array}{l}\text { Official } \\
\quad \text { languages }\end{array}$ & Dutch, Papiamentu & $\begin{array}{l}\text { Dutch, Papiamentu, } \\
\text { English }\end{array}$ & Dutch, English & Dutch, Papiamentu & Dutch, English & Dutch, English \\
\hline Currency $^{\mathrm{a}}$ & Aruban florin & $\begin{array}{l}\text { Netherlands Antillean } \\
\text { guilder }\end{array}$ & $\begin{array}{l}\text { Netherlands Antillean } \\
\text { guilder }\end{array}$ & United States dollar & $\begin{array}{l}\text { United States } \\
\text { dollar }\end{array}$ & $\begin{array}{l}\text { United States } \\
\text { dollar }\end{array}$ \\
\hline
\end{tabular}

${ }^{\text {a }}$ Government of the Netherlands (2020) What are the different parts of the Kingdom of the Netherlands? https://www.government.nl/topics/caribbeanparts-of-the-kingdom/question-and-answer/what-are-the-different-parts-of-the-kingdom-of-the-netherlands. Accessed 25 November 2020

${ }^{\mathrm{b}}$ Central Bureau of Statistics Aruba (2020) Quarterly demographic bulletin. https://cbs.aw/wp/wp-content/uploads/2020/06/QDB0320.pdf. Accessed 25 November 2020

${ }^{\mathrm{c}}$ Central Bureau of Statistics Curaçao (2020) Population tables. https://www.cbs.cw/population-tables. Accessed 25 November 2020

${ }^{\mathrm{d}}$ Department of Statistics Sint Maarten (2018) The population of Sint Maarten 2018. http://stat.gov.sx/downloads/LFS/Population_Factsheet_Sint Maarten_2018.pdf. Accessed 25 November 2020

${ }^{\mathrm{e}}$ Statistics Netherlands (2020) Caribbean Netherlands; population, sex, age and country of birth. https://opendata.cbs.nl/statline/\#/CBS/en/dataset/ 84712ENG/table?ts=1606311418329. Accessed 25 November 2020

${ }^{\mathrm{f}}$ Statistics Netherlands (2020) Caribbean Netherlands; population, births, deaths, migration. https://opendata.cbs.nl/statline/\#/CBS/en/dataset/ 83774ENG/table?ts=1606317359904. Accessed 25 November 2020

Bonaire and Curaçao was estimated to be at least 1 in 1331 inhabitants above the age of 12 years, which is the highest in the world (Westermann et al. 2003). This high prevalence is most likely due to a founder effect. Indeed, two common mutations in the $E N G$ gene have been identified in families with HHT in the former Netherlands Antilles and one of these mutations was also found in a Dutch family with the same disease haplotype (Gallione et al. 2000). Thus, it appears that at least one $E N G$ mutation has been introduced into the populations of Bonaire and Curaçao by a Dutch colonist (Gallione et al. 2000). Because of this high prevalence, a specialized HHT outpatient clinic has been established in Bonaire and Curaçao.

\section{Community genetics services}

\section{Prenatal screening and testing}

Prenatal ultrasonography to detect congenital anomalies in the second trimester is offered to all pregnant women in the Dutch Caribbean. Screening for trisomy 13, 18, and 21 can be performed (through non-invasive prenatal testing using cell-free DNA and/or nuchal translucency scan combined with maternal serum screening), although the indications and reimbursements differ between the islands. There is no data on uptake of these two first trimester screening tests, although local midwives and physicians estimate it to be low (personal communication). Invasive prenatal testing (chorionic villus sampling or amniocentesis) is only available on Aruba; women on the other islands have to go abroad for these prenatal diagnostic tests. Termination of pregnancy is not allowed by law in Aruba, Curaçao, and St. Maarten, although in Curaçao, there has been an "institutionalized tolerance" policy since 1999 (Boersma et al. 2012). On the BES-islands, termination of pregnancy was legalized after they became special municipalities of the Netherlands in 2010.

\section{Neonatal screening}

In 2013, it was decided by the Dutch Minister for Health, Welfare, and Sport to introduce blood spot screening in the BES-islands. Neonatal blood spot screening started in Bonaire on 1 January 2015, and in St. Eustatius and Saba in October of that same year. The screening program is coordinated by the local Public Health Services under the direction of the Dutch National Institute for Public Health and the Environment. Blood samples are sent to the Netherlands once per week and screened for a number of disorders, including congenital hypothyroidism, adrenogenital syndrome, 
hemoglobinopathies, cystic fibrosis, and several metabolic disorders (equal to the program of the Netherlands). Uptake of this neonatal screening (NBS) program is high: $>90 \%$ in Saba and St. Eustatius and $\geq 99 \%$ in Bonaire (in some years, uptake was $>100 \%$ in Bonaire because of high maternal mobility around childbirth, resulting in a higher number of screened newborns than registered live births). In the first 5 years of this NBS program, 1196 children were screened and four children were diagnosed with sickle cell disease. Additionally, one child was suspected of having $\mathrm{HbH}$ disease, but DNA testing has not been performed to confirm this (Wins et al. 2020).

In contrast to the BES-islands, there is no national NBS program in Aruba, Curaçao, and St. Maarten. However, there are hospital-based initiatives that offer NBS. Screening for congenital hypothyroidism is offered to newborns admitted to the pediatric department of the Dr. Horacio E. Oduber Hospital in Aruba and to all newborns delivered at Sint Maarten Medical Center. In Curaçao, screening for hemoglobinopathies in umbilical cord blood is offered to all newborns delivered at the Curaçao Medical Center, as well as screening for congenital hypothyroidism. In addition, screening for phenylketonuria is offered to newborns that are not or only partly of Afro-Caribbean ancestry, as phenylketonuria is less prevalent in populations with African ancestry. The percentage of newborns screened through these hospital-based programs is unknown.

\section{Clinical genetics service}

Until 2011, there was no local clinical genetics service in the Dutch Caribbean. In order to provide the pediatric population of these islands the same genetic care that is provided for other citizens of the Kingdom of the Netherlands, a collaboration between the local pediatricians and a clinical geneticist from the Netherlands was established, resulting in a bi-annual joint pediatric-genetics clinic. The Dutch clinical geneticist $(\mathrm{MvH})$ visits the pediatric departments of the local hospitals in Curaçao (since 2011), Aruba (since 2012), and Bonaire (since 2013) twice a year to evaluate patients suspected of having a genetic disorder. Pediatric patients from St. Maarten, Saba, and St. Eustatius are referred to the joint pediatric-genetics clinic at St. Maarten Medical Hospital since 2014. If indicated, blood samples are sent to the Netherlands for genetic testing to establish or confirm a diagnosis. Once a genetic diagnosis is established, patients or their parents/caregivers receive genetic counseling during a follow-up visit with the visiting Dutch clinical geneticist. Information material on the genetic disorder and inheritance pattern is provided in English or Dutch. We aim to provide information material in Papiamentu in the future, as this is the first language of the majority of the population in Aruba, Bonaire, and Curacao. Continuity of the service throughout the year is realized through electronic consultations between pediatricians and the clinical geneticist. The costs of genetic testing are reimbursed by the local health insurances, although there are limitations to the number and costs of genetic tests that can be requested on an annual basis. Because of these financial restrictions, gene panels based on next generation sequencing (NGS) are initially performed in the proband only. Segregation in the family is subsequently performed if it is necessary to establish the diagnosis (e.g., if a variant of unknown significance is identified). Trio whole exome sequencing is not routinely offered because of the high associated costs. With this approach, costs of genetic testing can be kept to a minimum, while diagnostic capacity is largely preserved. From 2011 to 2018, approximately one-quarter of the referred children received a genetic diagnosis with this program (unpublished data), thus ending the diagnostic odyssey for their parents, enabling them to make informed reproductive choices and guiding clinical management. In addition, the visiting clinical geneticist contributes to local research and genetic education of local physicians, with the aim of increasing awareness and knowledge of genetic conditions.

In line with a recent report on a medical genetics service on other Caribbean islands (Sobering et al. 2020), our experience is that, even when resources are limited, a program with a visiting clinical geneticist contributes significantly to healthcare in under-served communities. To formally study this, a $\mathrm{PhD}$ project by a clinical researcher (EV) is currently ongoing. This research project focuses on the outcomes of the established clinical genetics service, including clinical utility, cost-benefits, and perspectives of patients and parents, as there is a paucity of literature on these topics in the Caribbean. In addition, we aim to investigate our hypothesis that certain congenital anomalies and genetic diseases are more prevalent in the Dutch Caribbean, because of the small and relatively isolated populations on these islands.

Although the clinical genetics service was initially established for pediatric patients in collaboration with local pediatricians, many other medical specialists are now aware of this service and the frequency of non-pediatric genetic referrals is gradually increasing. To meet the growing demand for cancer and cardio genetics services as well, we aim to expand our service and provide appropriate genetic counseling and testing for these patients in the future. Presymptomatic genetic testing is however not (yet) covered by local insurance companies and not (yet) part of regular local medical care. Telemedicine might be an excellent option to support the implementation of these services when possible, since physical examination is not a requirement for the majority of these consultations. However, technology issues need to be addressed first, as a secure (complying with data protection regulations) and reliable broadband internet connection is not always available in the hospitals of the Dutch Caribbean. 


\section{Conclusion}

The islands of the Dutch Caribbean face several challenges, including limited access to specialized healthcare like clinical genetics. Community genetics services such as prenatal and neonatal screening are available on the islands, although the extent of these services differs between the islands. In order to provide clinical genetics services for the populations of the Dutch Caribbean, a bi-annual joint pediatric-genetics clinic has been established. Our strategy with a visiting clinical geneticist that includes collaboration with, and training and support of local specialists can be an example for other countries in which genetic testing and counseling services are not (yet) available. Future research should focus on the outcomes of these services, such as the clinical utility and cost-benefits, as well as the perspectives of patients and parents. Finally, the current COVID-19 pandemic accentuates the vulnerabilities of small island states, as they depend on external healthcare services. While medical transfers and visits from medical specialists remain essential, (further) implementation of telemedicine is prompted wherever possible, to provide continuation of specialized medical care.

\section{Declarations}

Ethical approval This article does not contain any studies with human or animal subjects.

Conflict of interest The authors declare no competing interests.

\section{References}

Boersma A, Alberts J, Bruijn JD, Meyboom BD, Kleiverda G (2012) Termination of pregnancy in Curaçao: need for improvement of sexual and reproductive healthcare. Global J Health Sci 4:30-38. https://doi.org/10.5539/gjhs.v4n3p30

Central Bureau of Statistics Curaçao (2020) Population tables. https:// www.cbs.cw/population-tables.
Gallione CJ, Scheessele EA, Reinhardt D, Duits AJ, Berg JN, Westermann CJ, Marchuk DA (2000) Two common endoglin mutations in families with hereditary hemorrhagic telangiectasia in the Netherlands Antilles: evidence for a founder effect. Hum Genet 107: 40-44. https://doi.org/10.1007/s004390000326

Rijksinstituut voor Volksgezondheid en Milieu (RIVM) (2013) Feasibility study for the implementation of the neonatal heel prick screening in the Dutch Caribbean. https://www.rivm.nl/publicaties/ uitvoeringstoets-neonatale-hielprikscreening-in-caribischnederland-2013.

Sobering AK, Li D, Beighley JS, Carey JC, Donald T, Elsea SH, Figueroa KP, Gerdts J, Hamlet A, Mirzaa GM, Nelson B, Pulst SM, Smith JL, Tassone F, Toriello HV, Walker RH, Yearwood KR, Bhoj EJ (2020) Experiences with offering pro bono medical genetics services in the West Indies: benefits to patients, physicians, and the community. Am J Med Genet C: Semin Med Genet 184(4): 1030-1041. https://doi.org/10.1002/ajmg.c.31871

Statistics Netherlands (2020) Caribbean Netherlands; population, sex, age and country of birth. https://opendata.cbs.nl/statline/\#/CBS/en/ dataset/84712ENG/table?ts=1606311418329.

Toro-Labrador G, Wever R, Martínez-Cruzado J (2003) Mitochondrial DNA analysis in Aruba: strong maternal ancestry of closely related amerindians and implications for the peopling of Northwestern Venezuela. Caribb J Sci 39:11-22

van der Dijs FP, van den Berg GA, Schermer JG, Muskiet FD, Landman H, Muskiet FA (1992) Screening cord blood for hemoglobinopathies and thalassemia by HPLC. Clin Chem 38:1864-1869

van Heyningen AM, Levenston MJ, Tamminga N, Scoop-Martijn EG, Wever RM, Verhagen AA, van der Dijs F, Dijck-Brouwer DA, Offriinga PJ, Muskiet FA (2009) Estimated incidence of sicklecell disease in Aruba and St. Maarten suggests cost-effectiveness of a universal screening programme for St. Maarten. West Indian Med J 58:301-304

Westermann CJ, Rosina AF, De Vries V, de Coteau PA (2003) The prevalence and manifestations of hereditary hemorrhagic telangiectasia in the Afro-Caribbean population of the Netherlands Antilles: a family screening. Am J Med Genet A 116a:324-328. https://doi.org/ 10.1002/ajmg.a.10002

Wins S, Verkerk PH, van der Ploeg K (2020) Monitor van de hielprikscreening in Caribisch Nederland 2019. Nederlandse Organisatie voor Toegepast Natuurwetenschappelijk Onderzoek (TNO). https://www.pns.nl/documenten/nhs-monitor-cn-2019 . Accessed 27 January 2021

Publisher's note Springer Nature remains neutral with regard to jurisdictional claims in published maps and institutional affiliations. 